\title{
ANTITUMOR ACTIVITY OF CRATEVA MAGNA IN TRANSPLANTABLE TUMOR MODELS IN MICE
}

\author{
ANKITA DEEP ${ }^{1}$, SINDHU R ${ }^{1}$, KENGANORA MRUTHUNJAYA², SANTHEPETE N MANJULA ${ }^{1 *}$
}

${ }^{1}$ Department of Pharmacology, JSS College of Pharmacy, JSS Academy of Higher Education and Research, Mysore, Karnataka, India.

${ }^{2}$ Department of Pharmacognosy, JSS College of Pharmacy, JSS Academy of Higher Education and Research, Mysore, Karnataka, India. Email: snmanjula@jssuni.edu.in

Received: 28 August 2019, Revised and Accepted: 27 September 2019

ABSTRACT

Objective: The present study aims to evaluate the anticancer and immunomodulatory activity of both the alcoholic and aqueous extracts of Crateva magna (ALCM and AQCM) in solid tumor model and ascites tumor model in mice.

\begin{abstract}
Methods: The study was divided into in vitro and in vivo sections. In vitro, antioxidant activity of both the extracts was evaluated by well-established antioxidant assays such as $\alpha, \alpha$-diphenyl- $\beta$-picrylhydrazyl radical scavenging, reducing power, and 3-ethylbenzothiazoline- 6 -sulfonic acid radical scavenging. Both the extracts were subjected for in vitro preliminary cytotoxicity screening by brine shrimp lethality assay and Trypan blue exclusion assay. In vivo antitumor activity of ALCM and AQCM was assessed at the doses of $100 \mathrm{mg} / \mathrm{kg}$ and $200 \mathrm{mg} / \mathrm{kg}$ bodyweight, respectively, by Dalton's Lymphoma ascites induced robust tumor model and Ehrlich Ascites Carcinoma induced ascites tumor model in mice. Substantial tumor volume, tumor weight, and \% inhibition of the tumor weight in treated and untreated groups were evaluated. In addition to the investigation of antitumor activity, the possible immunomodulatory activity was also assessed.
\end{abstract}

Results: The studies showed that the ALCM demonstrated more significant antioxidant activity. The results also showed more immunomodulatory activity when compared to AQCM.

Conclusion: The study proves that the plant extract is of higher therapeutic efficacy in cancer. However, the extracts require more exploration toward its usefulness in drug discovery.

Keywords: Crateva magna, Antitumor, Antioxidant, Immunomodulatory.

(C) 2019 The Authors. Published by Innovare Academic Sciences Pvt Ltd. This is an open access article under the CC BY license (http://creativecommons. org/licenses/by/4. 0/) DOI: http://dx.doi.org/10.22159/ajpcr.2019.v12i12.35479

\section{INTRODUCTION}

Cancer is a disease ranked as the second leading cause of morbidity next to cardiovascular diseases [1]. In spite of extensive global research aimed at amending the miserable outcomes of cancer, no apparent decline in the overall mortality rate seen over the past 30 years. From the ancient period, plants are useful in the management of cancer [2]. Over $60 \%$ of the presently used anticancer agents obtained in one or the other from natural sources such as plants, marine organisms, and microorganisms [3]. About 13\% of all human deaths occurred due to cancer. The American Cancer Society projected that around 7.6 million people die every year due to cancer [4]. Some of the new chemotherapeutic agents that are currently available for use in a clinical setting are plant-based components include Vinca alkaloids, taxane diterpenoids, epipodophyllotoxin ligands, camptothecin, and other derivatives of quinolone alkaloids.

Crateva magna (CM) belonging to the family Capparaceae commonly used in the treatment of urinary disorders that reoccur due to the progress of antibiotic resistance caused by the infecting organism. In traditional medicine, leaves have lithotriptic, diuretic, demulcent, and tonic properties. Externally, the paste of its leaves applied in cervical adenitis, abscess, and edematous wounds. The same adhesive is salutary in the rheumatic joint for relief of pain. In folk medicine, its stem pith used by the tribal people of Kandhamal district of Orissa known as Eastern Ghats of India. The bark of this plant used for lactation after childbirth, treatment of urinary disorders, bladder stones, fever, nausea, and gastrointestinal irritation. Earlier research was done on this plant reports the in vivo sedative and cytotoxic activities of the methanolic extract.
The alcoholic extract decreased the locomotor activity of mice in an elevated plus maze, open field, and hole cross tests. The alcoholic extract exhibited dose-dependent cytotoxicity in brine shrimp lethality assay with an $\mathrm{IC}_{50}$ of $59.67 \mu \mathrm{g} / \mathrm{ml}$ as compared to $0.45 \mu \mathrm{g} / \mathrm{ml}$ shown by standard vincristine sulfate [5] evaluated the bark of the plant for its antipyretic activity on TAB-VACCINE induced pyrexia in rabbits. The alcoholic extract of aerial parts of CM formed a significant decrease in the body temperature in hyperthermic rats. Remya et al. (2009) investigated the entire plant for the treatment of benign prostatic hyperplasia. Alam et al. (2006) evaluated the crude extract of leaves of CM for its antinociceptive activity in mice. The "acetic acid" analgesic test method in mice was used to assess the antinociceptive effect. Crude ethanolic extracts of CM (250-500 mg/kg PO) showed dose-dependent, antinociceptive effect against chemically induced nociceptive pain stimuli in mice. In vivo and in vitro antitumor activity of leaves of CM has not reported so far. Hence, the current study emphases the antitumor activity of ethanolic and aqueous extract of the CM.

\section{MATERIALS AND METHODS}

\section{Materials}

Plant material and extraction

The plantmaterial (fresh leaves of CM) was procured from Natural Remedies Pvt. Ltd., Bengaluru and was authenticated by Dr. M. N. Naganandini, Department of Pharmacognosy, JSS College of Pharmacy, Mysuru, India. The coarse powder was extracted with $95 \%$ ethanol in the Soxhlet extractor. The residue was dried over a water bath to obtain the alcoholic extract of CM (ALCM). The aqueous extract was prepared by cold maceration method. After completion of extraction, the marc was filtered through muslin cloth followed by filter paper and concentrated and dried on a water bath to obtain the aqueous extract of CM (AQCM). 
Cell lines

Dalton's Lymphoma ascites (DLA) and Ehrlich Ascites Carcinoma (EAC) cell lines were procured from Amala Cancer Research Center, Thrissur, India.

Animals

All the animal experiments and handling of animals were approved by the Institutional Animal Ethics Committee (IAEC), JSS College of Pharmacy, Mysuru, India (IAEC approval number 134/2013). Swiss albino mice of eight to 10 weeks old weighing between 25 and 30 g were selected for the study. Animals were acclimatized to the experimental room for 1 week before the experiment. Animals were maintained under controlled conditions of temperature $\left(27 \pm 2^{\circ} \mathrm{C}\right)$ and were caged in sterile polypropylene cages containing sterile paddy husk as bedding material with a maximum of six animals in each cage. The mice were fed on a standard diet and water ad libitum.

\section{Methods}

In vitro antioxidant activity using mice

$\alpha, \alpha$-Diphenyl- $\beta$-picrylhydrazyl (DPPH) free radical scavenging assay $2 \mathrm{ml}$ of $0.1 \mathrm{mM}$ of DPPH was added to $2 \mathrm{ml}$ of methanol. The absorbance was taken immediately, at a wavelength of $517 \mathrm{~nm}$, which serves as a control. $2 \mathrm{ml}$ of DPPH was added to $2 \mathrm{ml}$ of test extracts (ALCM and AQCM) and shaken well. The test samples were incubated for $30 \mathrm{~min}$. The absorbance was recorded against methanol as blank at a wavelength of $517 \mathrm{~nm}$ [6]. The \% scavenging activity and $\mathrm{IC}_{50}$ was determined [7].

$$
\% \text { scavenging activity }=\frac{\text { Absorbance of control }- \text { Absorbance of test }}{\text { Absorbance of control }}
$$

3-Ethylbenzothiazoline-6-sulfonic acid (ABTS) - decolorizing assay Different concentrations of test extracts (ALCM and AQCM) $(50,100,150$, 200,250 , and $300 \mu \mathrm{g} / \mathrm{ml}$ ) were reacted with $5 \mathrm{ml}$ of fresh $\mathrm{ABTS}^{++}$solution. Absorbance was measured against blank after 15 min of incubation in the dark at $734 \mathrm{~nm}$. L-Ascorbic acids were used as a standard. The \% scavenging activity was determined, and $\mathrm{IC}_{50}$ was calculated [8].

$$
\% \text { scavenging activity }=\frac{\text { Absorbance of control }- \text { Absorbance of test }}{\text { Absorbance of control }}
$$

\section{Reducing power assay}

$1 \mathrm{ml}$ of different concentrations of the sample $(20,40,60,80$, and $100 \mu \mathrm{g} / \mathrm{ml}$ ) were assorted with $2.5 \mathrm{ml}$ of phosphate-buffered saline (PBS) $(0.2 \mathrm{M}, \mathrm{pH} 7.6)$ and $2.5 \mathrm{ml}$ of potassium ferricyanide $(1 \% \mathrm{~W} / \mathrm{V})$. The combined solution was incubated at $50^{\circ} \mathrm{C}$ for $30 \mathrm{~min} .2 .5 \mathrm{ml}$ of trichloroacetic acid (TCA) $(10 \% \mathrm{~W} / \mathrm{V})$ was added to the mixture, which was then centrifuged at $3000 \mathrm{rpm}$ for $10 \mathrm{~min}$ [9]. $2.5 \mathrm{ml}$ of the upper layer of the solution was mixed with $2.5 \mathrm{ml}$ of distilled water and $0.5 \mathrm{ml}$ of $\mathrm{FeCl}_{3}(0.1 \% \mathrm{~W} / \mathrm{V})$, the absorbance was measured against blank at $700 \mathrm{~nm}$.

\section{In vitro cytotoxic activity}

Trypan blue exclusion assay

EAC and DLA cells were aspirated from the peritoneal cavity of tumorbearing mice. Two to three times, the cells were washed with PBS, and one million cells were incubated with different concentrations of ALCM and AQCM $(20,40,60,80$, and $100 \mu \mathrm{g} / \mathrm{ml})$ [10]. Cyclophosphamide $(50 \mu \mathrm{g} / \mathrm{ml})$ alone in a volume of $0.1 \mathrm{ml}$ was used as a control, in $1 \mathrm{ml}$ of PBS for $3 \mathrm{~h}$ at $37^{\circ} \mathrm{C}$ in sterile test tubes. $100 \mu \mathrm{L}$ of Trypan blue dye $(0.4 \%$ in PBS) was added after incubation, and the total number of dead (stained) and viable (unstained) cells were counted using a hemocytometer [11]:

$$
\% \text { cytotoxicity }=\frac{\text { No of stained cells }}{\text { Total no of cells }} \times 100
$$

Brine shrimp lethality assay

The test extracts of ALCM and AQCM were prepared using seawater. Ten Nauplii were transferred into sample vials and were treated with different concentrations of test compounds (100, 200, 300,400, and 500) micromolar in $5 \mathrm{ml}$ of seawater for $24 \mathrm{~h}$. A drop of the suspension was added to each vial. Vials were maintained under illumination. After $24 \mathrm{~h}$, the number of surviving Nauplli was counted using $\times 3$ magnifying glass, and the percentage cytotoxicity and $\mathrm{IC}_{50}$ values were determined [12].

$$
\% \text { lethality }=\frac{(\text { Dead nauplii }- \text { Total nauplii })}{\text { Total nauplii }} \times 10
$$

In vivo antitumor activity of ALCM and AQCM against EAC inoculated ascites tumor model

EAC cells were procured from the peritoneal cavity of an EAC bearing mouse, after 15 days of tumor transplantation. The ascitic fluid was withdrawn and suitably diluted in phosphate buffer saline to obtain a stock cell concentration of $10^{7}$ cells per ml. For ascitic tumor $2.5 \times 10^{6}$, EAC cells $(0.25 \mathrm{ml}$ of stock suspension) were injected intraperitoneally to each mouse [13]. Treatment was started after $24 \mathrm{~h}$ of tumor inoculation and was continued for 15 days, and the various parameter was evaluated [14]:

$\%$ Increase in body weight as compared to "0" day weight

The animals were weighed on the day of inoculation and once in 3 days after that in the post-inoculation period. The $\%$ increase in body weight was calculated as follows [15]:

$$
\% \text { increase in weight }=\frac{(\text { Animal weight on a respected day })-1}{\text { Weight of animal on day } 0} \times 100
$$

Mean survival time (MST) and percentage increase in life span (\%ILS)

A total number of days an animal survived from the day of tumor inoculation were counted. Subsequently, the MST was calculated. The \%ILS was calculated as:

$$
\% \text { increase in life span }=\frac{([\text { Mean survival time test }-}{\text { Mean survival time concentration }])} \times 100
$$

\section{Hematological parameters}

To assess the hematological status of treated animals, blood was withdrawn from retro-orbital plexus of the animals. The collected blood was transferred into sodium citrate treated microcentrifuge tubes, and the following parameters were monitored [16].

Determination of total white blood cell (WBC) count

Blood was drawn up to 0.5 marks of WBC pipette, and excess of blood from the tip was wiped off. The collected blood was diluted with WBC diluting fluid (1\% acetic acid, $1 \mathrm{ml}$ glacial acetic acid was added to $99 \mathrm{ml}$ distilled water) up to mark 11 and was mixed thoroughly for $1 \mathrm{~min}$. The fluid was charged on the counting chamber of hemocytometer. The total number of cells in all the four corner squares of WBC counting area was counted using $\times 10$ objective. Then, the total WBC count was calculated from the number of cells/mm using the formula:

Total WBC count $=$ Total number of cells in the WBC counting area $\times 50$

Determination of total red blood cell (RBC) count

Blood was drawn up to 0.5 marks of RBC pipette, and the excess of blood was wiped off from the tip. Then, the pipette was filled to 101 marks with RBC diluting fluid and mixed thoroughly for $1 \mathrm{~min}$. The fluid was charged on the counting chamber of hemocytometer. The total number of cells in the RBC counting area was counted using $\times 45$ objective. The average number of cells $/ \mathrm{mm}^{3}$ was calculated using the formula:

Total RBC count $=$ Total number of cells in the RBC counting area $\times 1000$

Where 1000 is the volume of RBC counting area.

\section{Estimation of serum biomarkers}

Estimation of serum glutamic oxaloacetic transaminase (SGOT)

Four volumes of reagent-1 (TRIS, L-Aspartate, malate dehydrogenase, and lactate dehydrogenase $[\mathrm{LDH}]$ ) were mixed with one volume of 
reagent-2 (alpha-ketoglutarate, NADH). These two reagents were mixed and incubated for $1 \mathrm{~min}$ at $37^{\circ} \mathrm{C}$. Absorbance was measured after 1 min using Merck Semi Auto Analyzer [17].

Estimation of serum glutamic pyruvate transaminase (SGPT)

The $1000 \mu \mathrm{l}$ of a working solution consisting of Tris buffer, L-alanine, LDH, $\alpha$-ketoglutarate, and NADH and $10 \mu$ of sample solution were mixed and incubated for $1 \mathrm{~min}$. Absorbance was read after 1 min using Merck Semi Auto Analyzer.

\section{Estimation of Alkaline phosphatase (ALP)}

Four volumes of reagent- 1 (diethanolamine, and magnesium chloride) were mixed with one volume of reagent-2 ( $\mathrm{p}$-Nitrophenyl phosphate). The $500 \mu \mathrm{l}$ of working solution and $10 \mu \mathrm{l}$ of sample solution were incubated for $50 \mathrm{~s}$, and absorbance was read using semi auto analyzer.

\section{Estimation of $L D H$}

Four volumes of reagent-1 (imidazole pyruvate-65mmol/L) were mixed with one volume of Reagent-1 (NADH-0.18 mmol/L) and were incubated. $3.0 \mu \mathrm{L}$ of working sample and $50 \mu \mathrm{L}$ of sample solution were incubated. Then, the initial absorbance of the sample was measured. The absorbance was read at the 1-min interval and for 3 min after that. The difference between the absorbance and the average absorbance per minute was calculated $(\Delta \mathrm{A} / \mathrm{min})$.

\section{Estimation of liver endogenous antioxidant enzymes}

$3 \mathrm{ml}$ of hydrogen peroxide phosphate buffer solution was added to $50 \mu \mathrm{l}$ of tissue homogenate, and absorbance was measured at $240 \mathrm{~nm}$ [18].

\section{Estimation of glutathione-S-transferase (GSH)}

$500 \mu \mathrm{L}$ of TCA solution was added to $500 \mu \mathrm{l}$ of tissue homogenate, and then it was centrifuged. $500 \mu \mathrm{l}$ of supernatant was incubated with $3 \mathrm{ml}$ of PBS and $500 \mu \mathrm{L}$ DTNB for $10 \mathrm{~min}$ at room temperature. Absorbance was read at $412 \mathrm{~nm}$ against blank, and glutathione concentration was calculated.

\section{Estimation of superoxide dismutase (SOD)}

$1850 \mu \mathrm{L}$ of carbonate buffer $0.1 \mathrm{M}$ was added to $50 \mu \mathrm{l}$ of tissue homogenate. $100 \mu \mathrm{l}$ of adrenaline was added directly in cuvette after putting in ultraviolet cuvette holder, absorbance was read at $480 \mathrm{~nm}$ (A0-A60) (Kinetic method).

\section{DNA fragmentation assay}

A DNA ladder represents a band of DNA molecules of varying lengths separated in agarose gel by electrophoresis. Agarose was added to electrophoresis buffer to prepare gel. The solution was placed in a microwave oven until the agarose particles were liquefied. The molten agarose was cooled, and ethidium bromide was added, and the gel was prepared. A fixed number of cells were treated with different concentration fractions, vehicle control, and standard for $48 \mathrm{~h}$. Cells were then collected, centrifuged, and lysis buffer was added to the cell pellet. Cell pellet in lysis buffer was incubated for $1 \mathrm{~h}$ with RNAse solution for $1 \mathrm{~h}$. The processed cells were cooled and loaded into wells of agarose gel followed by electrophoresis. Images were taken using a gel documentation system [19].

In vivo antitumor activity of ALCM and AQCM against DLA inoculated tumor model

After 15 days of tumor transplantation, the DLA cells were aspirated from the peritoneal cavity of DLA bearing mice. Tumor viability was determined by Trypan blue exclusion test, and a total number of viable cells were counted using hemocytometer. The ascitic fluid was appropriately diluted in saline to get a concentration of $10^{7}$ cells $/ \mathrm{ml}$ of tumor cell suspension. Around $0.1 \mathrm{ml}$ of this solution was injected subcutaneously to the right hind limb of mice to obtain a solid tumor. After $24 \mathrm{~h}$ tumor inoculation, the treatment was started and was continued for 15 days, tumor volume, and tumor weight was assessed [20].

\section{Tumor volume}

Vernier caliper was used to measure the radii of developing tumor at 5 days interval for 1 month, and tumor volume was calculated using the formula:

$$
V=4 / 3 \pi d c^{2}
$$

Where $\mathrm{c}$ and $\mathrm{d}$ represent the major and minor radii.

Tumor weight

Animals were sacrificed at the end of the $4^{\text {th }}$ week under anesthesia using diethyl ether; the tumor was extirpated and weighed. The percentage inhibition was calculated by the formula:

$$
\% \text { Inhibition }=(1-\mathrm{D} / \mathrm{C}) \times 100
$$

Where $\mathrm{C}$ is the average tumor weight of control group, $\mathrm{D}$ is that of the treated group.

\section{In vivo immunomodulatory activity}

Carbon clearance test

Swiss albino mice of $25-30 \mathrm{~g}$ of body weight were used in the experiment. Animals were randomized into the following six groups comprising six animals each. Animals were given the test extracts for 2 days. The mice were administered with carbon ink suspension through tail vein after $48 \mathrm{~h}$ of intraperitoneal injection. Blood samples were collected from the retro-orbital vein using glass capillaries at $5 \mathrm{~min}$ and $15 \mathrm{~min}$ [21]. Collected blood samples were mixed with $0.1 \%$ sodium carbonate solution for the lysis of erythrocytes. Absorbance was measured using the spectrophotometer at $675 \mathrm{~nm}$. The phagocytic activity was expressed by the phagocytic index (K) [22].

$$
\mathrm{K}=\frac{\left(\operatorname{lnOD}_{1}-\operatorname{lnOD}_{2}\right)}{\left(\mathrm{t}_{2}-\mathrm{t}_{1}\right)}
$$

Where,

$\mathrm{OD}_{1}$ and $\mathrm{OD}_{2}$ are optical densities at time $\mathrm{t}_{1}$ and $\mathrm{t}_{2}$.

The clearance rate is expressed as the half-life period of carbon ink in the blood.

$$
\mathrm{t}^{1} 1 / 2=0.693 / \mathrm{K}
$$

\section{Delayed type hypersensitivity}

Daily treatment of test extracts was given to the mice 5 days before the challenge. Control received the vehicle on each day. On day 0 , all animals were immunized with $20 \mu \mathrm{l}$ of sheep RBC (SRBC) solution $\left(5 \times 10^{9} \mathrm{SRBC} / \mathrm{ml}\right)$ injected subcutaneously into their right hind footpad. After 5 days of treatment, the thickness of each animal's footpad was measured just before the challenge using a digital plethysmometer. The animals were then challenged by injecting the $20 \mu \mathrm{l}$ of SRBC solution into the left hind footpad (deemed time 0). Foot thickness was remeasured after $24 \mathrm{~h}$ [23]. The difference between the thickness of left foot just before and after challenge (in mm) was taken as the measure of DTH.

$$
\text { DTH response }=\frac{\text { SRBC treatment paw }- \text { saline treated paw }}{\text { SRBC treated paw }} \times 100
$$

\section{Statistical analysis}

All experiments were done in triplicate, and values were reported as mean \pm standard error of the mean. Statistical analysis was by one-way ANOVA followed post hoc Tukey's multiple comparison analysis. The level of significance was set up at $\mathrm{p}<0.05$.

\section{RESULTS}

DPPH-free radical scavenging assay

Both extracts of ALCM and AQCM exhibited dose-dependent free radical scavenging activity. The $\mathrm{IC}_{50}$ of $\mathrm{AQCM}$ and $\mathrm{ALCM}$ was found to 


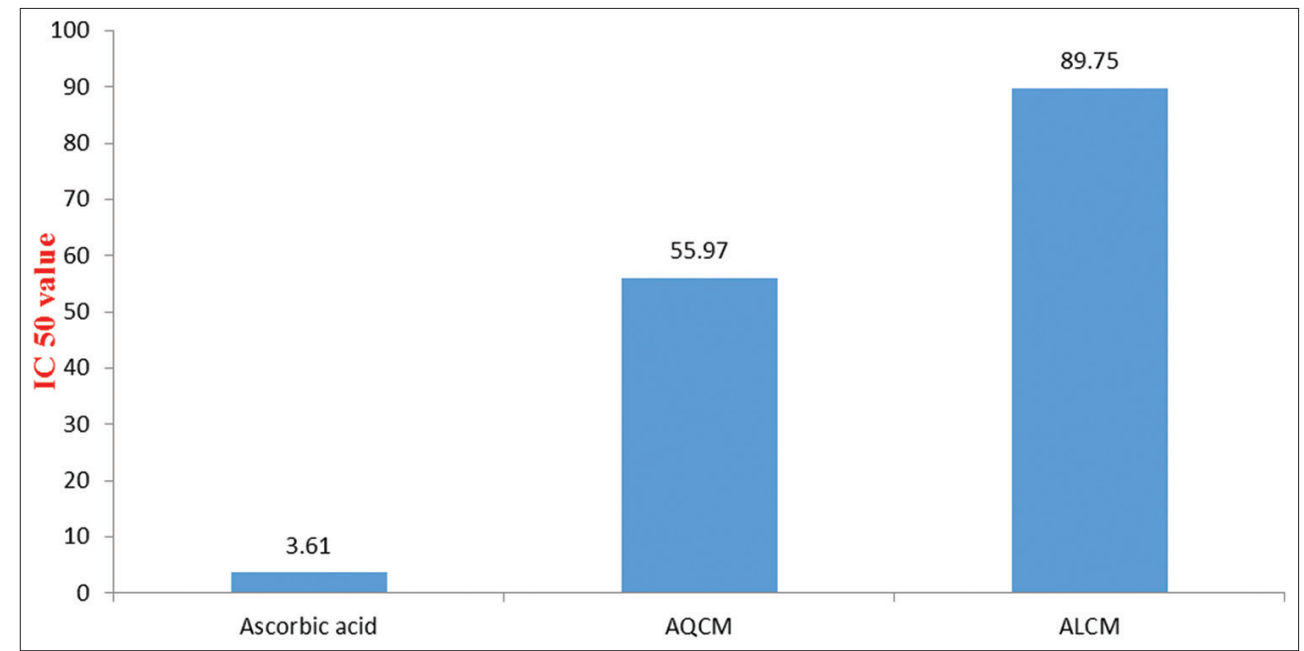

Fig. 1: 3-Ethylbenzothiazoline-6-sulfonic acid radical scavenging activity of alcoholic extracts of Crateva magna (CM) and aqueous extracts of $\mathrm{CM}$ with respect to the standard. All values are represented as mean \pm standard error of the mean, $\mathrm{n}=3$

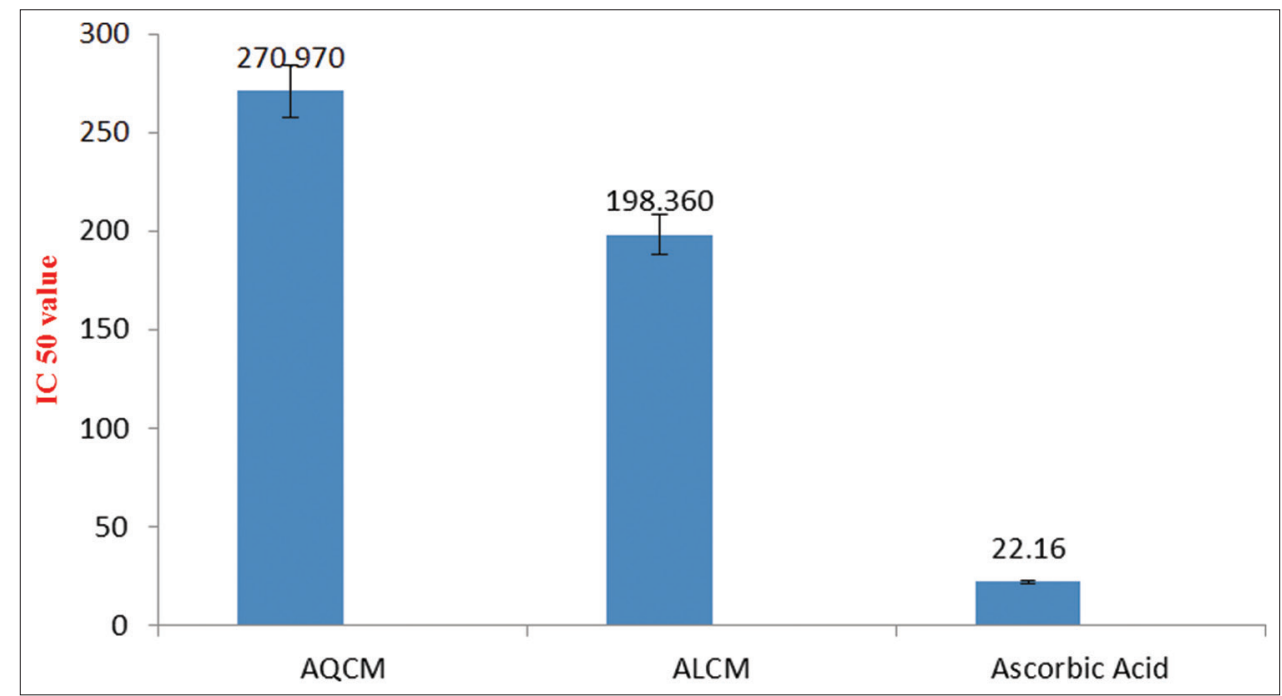

Fig. 2: 3-ethylbenzothiazoline-6-sulfonic acid radical scavenging IC $_{50}$ of alcoholic extracts of Crateva magna (CM) and aqueous extracts of $\mathrm{CM}$ with respect to the standard. All values are represented as mean \pm standard error of the mean, $n=3$

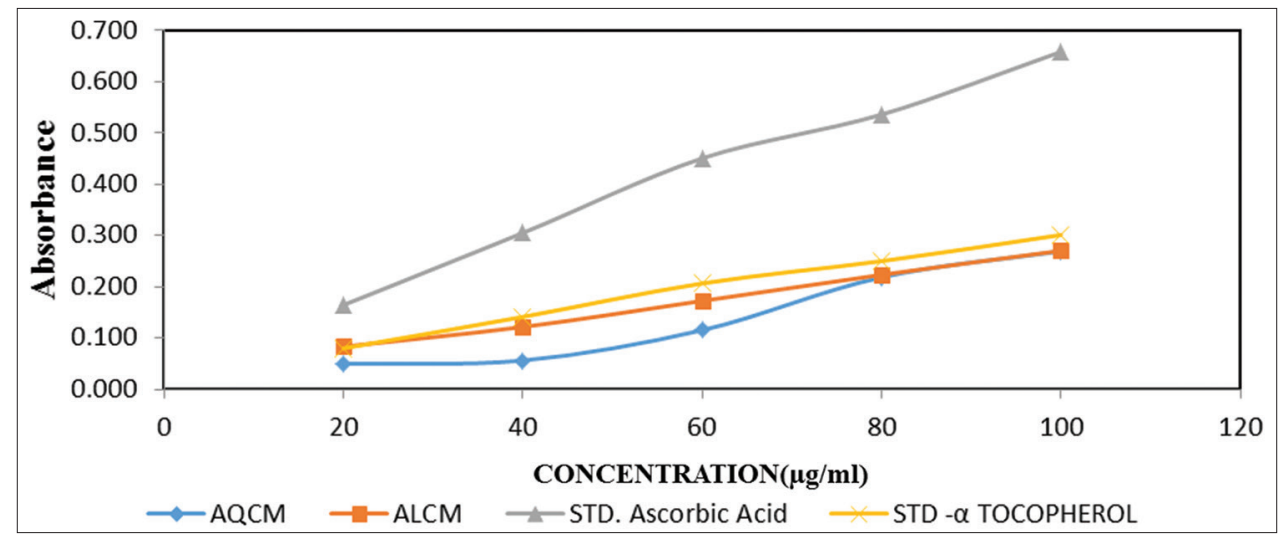

Fig. 3: Reducing power activity of alcoholic extracts of Crateva magna (CM) and aqueous extracts of CM with respect to the standard. All the values are represented mean \pm standard error of the mean, $n=3$

be $89.75 \pm 0.001 \mu \mathrm{g} / \mathrm{ml}$ and $55.97 \pm 0.002 \mu \mathrm{g} / \mathrm{ml}$, respectively, when compared to ascorbic acid with an $\mathrm{IC}_{50}$ of $3.6 \pm 0.001 \mu \mathrm{g} / \mathrm{ml}$ which are shown in Fig. 1.
ABTS-decolorizing assay

Both the extracts ALCM and AQCM exhibited dose-dependent free radical scavenging activity. The $\mathrm{IC}_{50}$ of $\mathrm{AQCM}$ and ALCM was found 
to be $268.70 \pm 0.5 \mu \mathrm{g} / \mathrm{ml}$ and $270.07 \pm 0.38 \mu \mathrm{g} / \mathrm{ml}$, respectively, when compared to ascorbic acid with an $\mathrm{IC}_{50}$ of $22.16 \pm 0.4 \mu \mathrm{g} / \mathrm{ml}$, as shown in Fig. 2.

Reducing power assay

Reducing power assay of ALCM and AQCM is shown in Fig. 3:
Trypan blue exclusion assay

In vitro cytotoxicity of extracts, ALCM and AQCM on EAC cells were determined by Trypan blue exclusion assay. Both the extracts showed dose-dependent cytotoxicity with an $\mathrm{IC}_{50}$ of $298 \pm 0.50$ and $356 \pm 0.62 \mu \mathrm{g} / \mathrm{ml}$, respectively. The percentage cytotoxicity of ALCM and AQCM on EAC cells by Trypan blue exclusion assay is shown in Fig. 4.

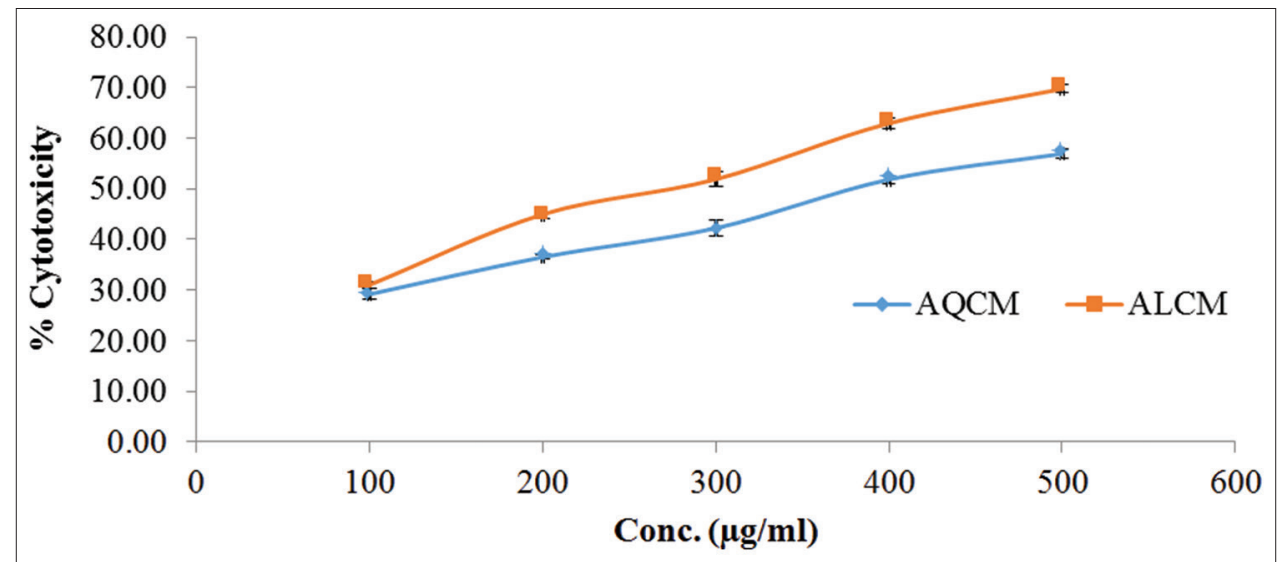

Fig. 4: Percentage cytotoxicity of alcoholic extracts of Crateva magna (CM) and aqueous extracts of CM on Ehrlich Ascites Carcinoma cells by Trypan blue exclusion assay. All values are expressed as mean \pm standard error of the mean, $n=3$

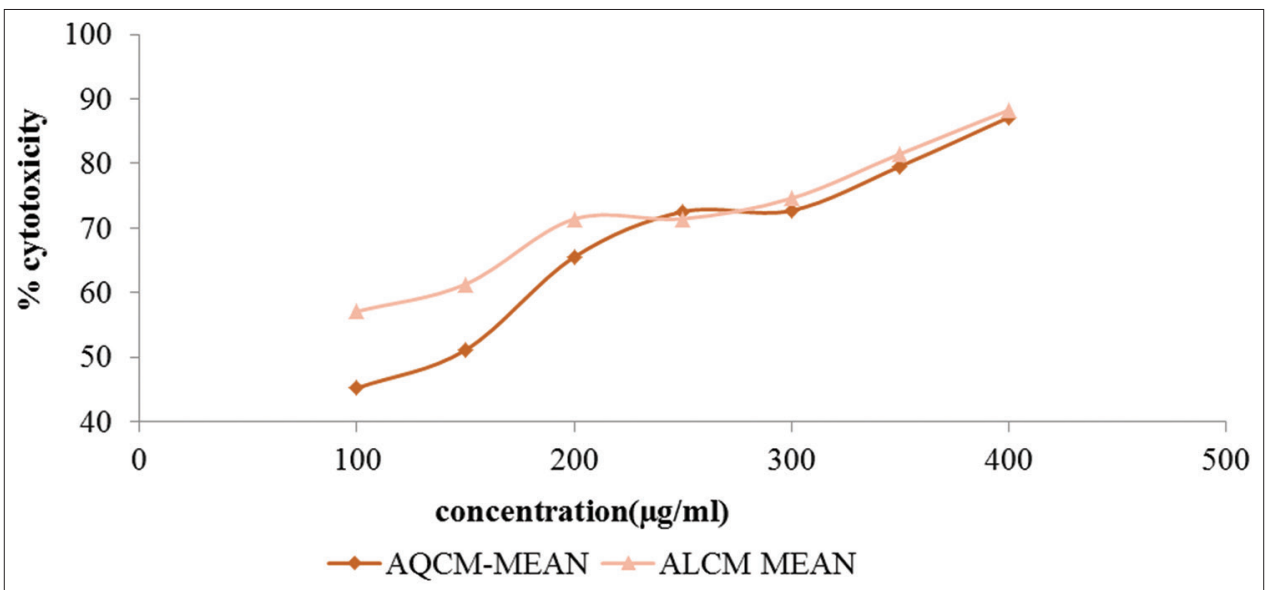

Fig. 5: Percentage lethality of alcoholic extracts of Crateva magna (CM) and aqueous extracts of CM by brine shrimp lethality assay. All values are expressed as mean \pm standard error of the mean, $n=3$

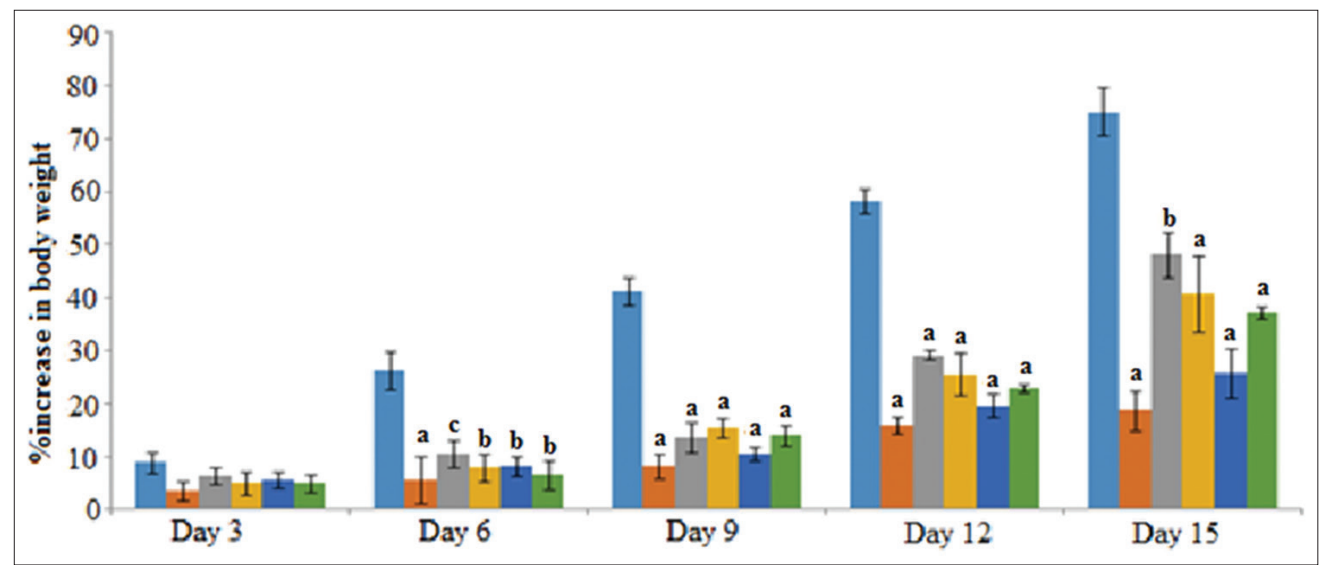

Fig. 6: Effect of alcoholic extracts of Crateva magna (CM) and aqueous extracts of CM on body weight changes in Ehrlich Ascites Carcinoma inoculated mice. All values represent mean \pm standard error of the mean, $n=6$. Where ${ }^{\mathrm{a} p}<0.05$ when compared to normal, ${ }^{\mathrm{b}} \mathrm{p}<0.05$ when compared to control. Data were analyzed by one-way ANOVA followed post hoc Tukey's multiple comparisons. Where, $\square$ Control (CMC 0.25\%),

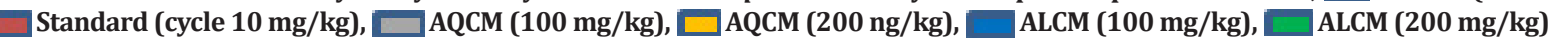


Brine shrimp lethality assay

Brine shrimp lethality assay was carried out on both the extracts. ALCM and AQCM showed dose-dependent cytotoxicity with an $\mathrm{IC}_{50}$ of $88.74 \pm 0.62$ and $119.68 \pm 0.82 \mu \mathrm{g} / \mathrm{ml}$, respectively. The percentage lethality of ALCM and AQCM by brine shrimp lethality assay is shown in Fig. 5.

\section{Effect of AQCM and ALCM on body weight changes}

Substantial increase in body weight was seen in EAC inoculated control animals with a maximum growth of $75.0 \pm 4.5 \%$ on day 15 compared to day 0 . The cyclophosphamide treatment significantly reduced body weight $(18.67 \pm 3.6 \%)$ compared to control. ALCM treatment at $200 \mathrm{mg} / \mathrm{kg}$ significantly decreased the tumor-induced percentage increase in the body weight $(37.19 \pm 1.1 \%)$, and the efficacy was compared with standard. The effect of ALCM and AQCM on body weight changes in EAC inoculated animals is shown in Fig. 6.

\section{Effect of ALCM and AQCM on MST and \% increase in the life span of EAC inoculated mice}

MST of EAC inoculated mice was $15.167 \pm 0.7$ days. Standard cyclophosphamide treatment at $10 \mathrm{mg} / \mathrm{kg}$ significantly improved the MST to $22.83 \pm 1.22$ days when compared to control. ALCM at $200 \mathrm{mg} / \mathrm{kg}$ increased the MST to $20.00 \pm 0.816$ days, respectively, when compared to control. The \%ILS of mice treated with ALCM at $200 \mathrm{mg} / \mathrm{kg}$ was $31.87 \%$.

\section{Effect of ALCM and AQCM on hematological parameters in EAC} inoculated mice

To assess the influence of ALCM and AQCM treatment on hematological parameters, the total RCBs, WBCs, and hemoglobin content of all the treatment groups were checked on the $15^{\text {th }}$ day of tumor inoculation.

\section{Effect on total WBC}

A significant rise in total WBC count was seen in EAC inoculated control animal $\left(20.63 \pm 0.91\right.$ cells $\left./ \mathrm{mm}^{3}\right)$ when compared to the normal animal $\left(7.01 \pm 0.53\right.$ cells $\left./ \mathrm{mm}^{3}\right)$. Standard cyclophosphamide treatment at a dose of $10 \mathrm{mg} / \mathrm{kg}$ resulted in a reduction in the WBC count to $\left(6.05 \pm 0.86\right.$ cells $\left./ \mathrm{mm}^{3}\right)$ when compared with control. ALCM at dose $100 \mathrm{mg} / \mathrm{kg}$ and $200 \mathrm{mg} / \mathrm{kg}$ significantly reversed the elevated WBC to $11.67 \pm 0.69$ cells $/ \mathrm{mm}^{3}$ and $13.72 \pm 0.63$ cells $/ \mathrm{mm}^{3}$ when compared to control.

\section{Total RBC}

A significant decrease in total RBC count was seen in EAC inoculated control animal $\left(2.84 \pm 0.05\right.$ cells $\left./ \mathrm{mm}^{3}\right)$ when compared with the normal mice $\left(5.53 \pm 0.34\right.$ cells $\left./ \mathrm{mm}^{3}\right)$. Treatment with cyclophosphamide $10 \mathrm{mg} / \mathrm{kg}$ significantly reversed this reduction to $5.16 \pm 0.09$ cells $/ \mathrm{mm}^{3}$ as compared to control; and ALCM at $100 \mathrm{mg} / \mathrm{kg}$ doses increased the total RBC count to $3.51 \pm 0.81$ and $4.08 \pm 0.19$ cells $/ \mathrm{mm}^{3}$ when compared to control animal.

\section{Effect of ALCM and AQCM on serum enzyme levels}

To assess the influence of ALCM and AQCM treatment on serum enzyme levels, the ALP, SGOT, and SGPT of all the treatment groups were checked on the $15^{\text {th }}$ day of tumor inoculation.

\section{Effect on serum glutamic oxaloacetic transaminase (SGOT)}

A significant increase in serum SGOT level was seen in EAC inoculated controlanimal ( $74.967 \pm 2.5 \mathrm{mg} / \mathrm{kg})$ when compared to the normal animal $(39.98 \pm 3.305 \mathrm{mg} / \mathrm{kg})$. Cyclophosphamide at $10 \mathrm{mg} / \mathrm{kg}$ reversed tumorinduced elevation in SGOT level $(53.63 \pm 2.565 \mathrm{mg} / \mathrm{kg})$ when compared with control. ALCM and AQCM at dose of $200 \mathrm{mg} / \mathrm{kg}$ decreased the elevated SGOT level to $60.083 \pm 2.735 \mathrm{mg} / \mathrm{kg}$ and $61.867 \pm 3.635 \mathrm{mg} / \mathrm{kg}$ compared to control.

\section{Effect on SGPT}

A significant increase in serum SGPT level was seen in EAC inoculated control animal $(62.30 \pm 3.195 \mathrm{mg} / \mathrm{kg})$ when compared to the normal animal (19.82 $\pm 1.275 \mathrm{mg} / \mathrm{kg})$. Cyclophosphamide at $10 \mathrm{mg} / \mathrm{kg}$ reversed tumor-induced elevation in SGPT level $(35.750 \pm 3.605 \mathrm{mg} / \mathrm{kg})$ when compared with control. ALCM and AQCM at both doses significantly decreased the elevated SGPT level to $41.700 \pm 3.445 \mathrm{mg} / \mathrm{kg}$ and $44.467 \pm 1.765 \mathrm{mg} / \mathrm{kg}$ compared to control.

\section{Effect on $A L P$}

A significant increase in serum ALP level was observed in the EAC inoculated control animal $(69.83 \pm 1.145 \mathrm{mg} / \mathrm{kg})$ when compared to the normal animal $(22.69 \pm 1.605 \mathrm{mg} / \mathrm{kg})$. Standard cyclophosphamide treatment at $10 \mathrm{mg} / \mathrm{kg}$ reversed tumor-induced elevation in the ALP level $(30.10 \pm 0.845 \mathrm{mg} / \mathrm{kg})$ when compared with control. ALCM and AQCM at the dose of $200 \mathrm{mg} / \mathrm{kg}$ significantly decreased the elevated ALP level to $39.100 \pm 0.845 \mathrm{mg} / \mathrm{kg}$, and $43.11 \pm 2.065 \mathrm{mg} / \mathrm{kg}$, and the reduction in ALP level was comparable to standard.

\section{Effect on serum $L D H$}

A significant increase in serum LDH level was seen in EAC inoculated control animal $(238.00 \pm 12.35 \mathrm{mg} / \mathrm{kg})$ when compared with control. ALCM at $200 \mathrm{mg} / \mathrm{kg}$ dose reversed tumor-induced elevation of LDH to $140.32 \pm 2.055 \mathrm{mg} / \mathrm{kg}$.

\section{Evaluation of liver endogenous antioxidant enzymes}

To assess the influence of ALCM and AQCM treatment on endogenous liver antioxidant levels, all the treatment groups were checked on the $15^{\text {th }}$ day of tumor inoculation.

\section{Effect of GSH}

A significant decrease of GSH concentration was observed in liver homogenate of ECA inoculated control mice $0.850 \pm 0.15 \mathrm{mg} / \mathrm{kg}$ when compared to normal animal $2.950 \pm 0.35 \mathrm{mg} / \mathrm{kg}$. Cyclophosphamide at a dose of $10 \mathrm{mg} / \mathrm{kg}$ significantly reversed the tumor-induced decrease in GSH concentration $1.78 \pm 0.15 \mathrm{mg} / \mathrm{kg}$ when compared with control. ALCM at $200 \mathrm{mg} / \mathrm{kg}$ significantly reversed GSH concentration to $1.574 \pm 0.2305 \mathrm{mg} / \mathrm{kg}$, and the efficacy was compared with the standard group.

\section{Effect of $S O D$}

A significant decrease in SOD concentration was observed in liver homogenate of EAC inoculated control mice $2.28 \pm 0.25 \mathrm{mg} / \mathrm{kg}$ when compared tonormalanimal $4.54 \pm 0.25 \mathrm{mg} / \mathrm{kg}$.Standard cyclophosphamide treatment at $10 \mathrm{mg} / \mathrm{kg}$ dose significantly reversed the tumor-induced decrease in SOD concentration $3.92 \pm 0.155 \mathrm{mg} / \mathrm{kg}$ when compared with control. ALCM at $200 \mathrm{mg} / \mathrm{kg}$ reversed GSH concentration to $3.09 \pm 0.25 \mathrm{mg} / \mathrm{kg}$ significantly in treated animals, the efficacy was compared with the standard group.

\section{Influence of extracts on DNA fragmentation assay}

The effect of extracts on DNA fragmentation assay is shown in Fig. 7:

In vivo anticancer activity of ALCM and AQCM on DLA inoculated solid tumor model

The weight of solid tumor in the control animal was found to be $6.85 \pm 0.226 \mathrm{~g}$ by the end of the $4^{\text {th }}$ week. Cyclophosphamide at $10 \mathrm{mg} / \mathrm{kg}$ dose showed a significant reduction in the solid tumor weight by $85.76 \pm 1.02 \mathrm{~g}$ when compared to control. ALCM and AQCM at the dose of $200 \mathrm{mg} / \mathrm{kg}$ caused a significant reduction in the solid tumor weight when compared with control. ALCM at a dose of $200 \mathrm{mg} / \mathrm{kg}$ was more effective in reducing the tumor weight by $54.02 \pm 6.3 \%$, the extent of tumor growth inhibition was not comparable to standard.

\section{Carbon clearance test}

There was an increased clearance of carbon particles from blood after administration of ALCM at $100 \mathrm{mg} / \mathrm{kg}$ and $200 \mathrm{mg} / \mathrm{kg}$ p.o. It is specified by a significant rise in the phagocytic index when compared to the control group. The effect of ALCM and AQCM on the phagocytic index is shown in Fig. 8. 


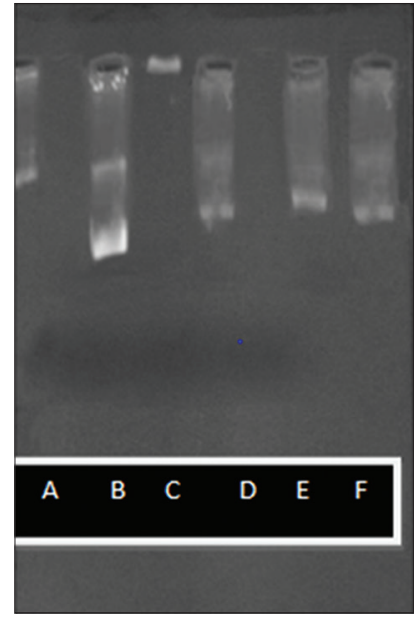

Fig. 7: Effect of extracts on DNA fragmentation assay. Where C-control, B-standard, A-alcoholic extracts of Crateva magna (ALCM) $(100 \mathrm{mg} / \mathrm{kg})$, D-ALCM $(200 \mathrm{mg} / \mathrm{kg}), \mathrm{E}$-aqueous extracts of CM (AQCM) (100mg/kg), F-AQCM- $(200 \mathrm{mg} / \mathrm{kg})$

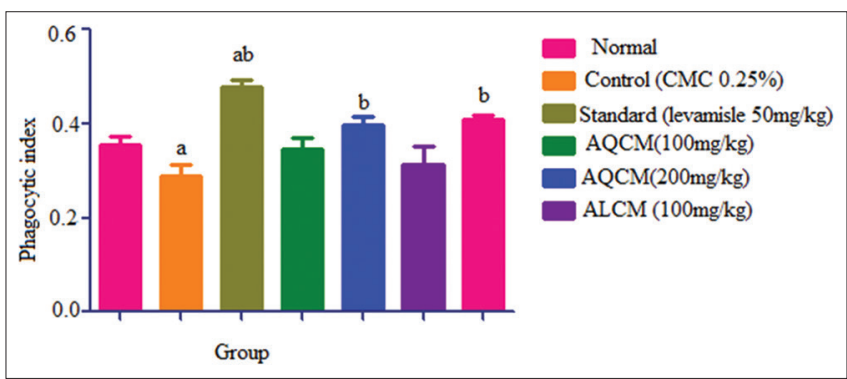

Fig. 8: Effect of alcoholic extracts of Crateva magna (CM) and aqueous extracts of $\mathrm{CM}$ on the phagocytic index. All values are represented as mean \pm standard error of the mean, $n=6$. Where ${ }^{\mathrm{a}} \mathrm{p}<0.05$ when compared to normal, ${ }^{\mathrm{b}} \mathbf{p}<\mathbf{0 . 0 5}$ when compared to control. The data were analyzed by one-way ANOVA followed by post hoc Tukey's multiple comparison test

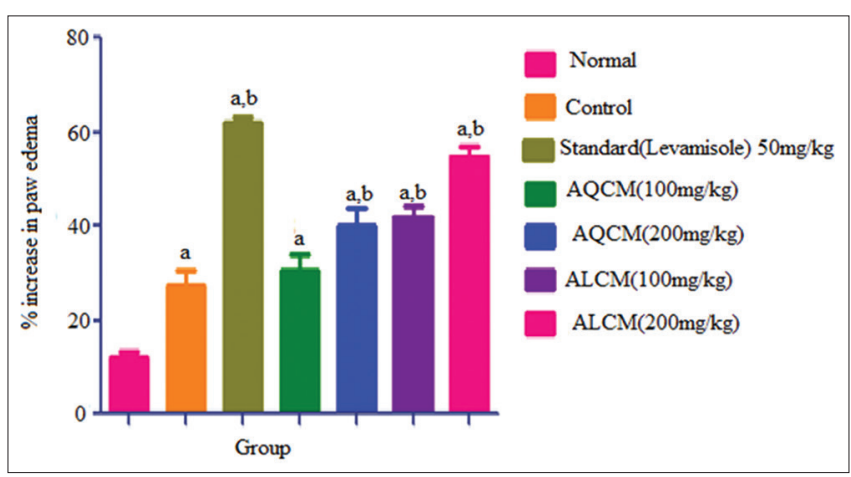

Fig. 9: Effect of alcoholic extracts of Crateva magna (CM) and aqueous extracts of $\mathrm{CM}$ on the paw volume in mice. All values represent mean \pm standard error of the mean, $n=6$ where ${ }^{a} p<0.05$ when compared to normal, ${ }^{b} \mathbf{p}<0.05$ when compared to control. The data were analyzed by one-way ANOVA followed by post hoc Tukey's multiple comparison test

\section{Delayed-type hypersensitivity}

Administration of both ALCM $100 \mathrm{mg} / \mathrm{kg}$ and $200 \mathrm{mg} / \mathrm{kg}$ p.o. and AQCM $100 \mathrm{mg} / \mathrm{kg}$ and $200 \mathrm{mg} / \mathrm{kg}$ p.o. showed a dose-dependent increase in the paw volume in mice when compared with the control group. ALCM $200 \mathrm{mg} / \mathrm{kg}$ and AQCM $200 \mathrm{mg} / \mathrm{kg}$ showed a maximum of $54.88 \pm 2.40 \%$ paw volume. The effect of ALCM and AQCM on the paw volume in mice is shown in Fig. 9. $39.92 \pm 4.01 \%$ increase in paw volume, which was significant when compared to control. The effect of ALCM and AQCM on the paw volume in mice is shown in Fig. 9.

\section{DISCUSSION}

The current study was designed to explore the possible antitumor activity of CM in transplantable tumor models. The research involves DLA induced and EAC induced ascites robust tumor model. Based on encouraging results, both the extracts in vitro antioxidant assays and preliminary cytotoxic assay were proceeded further for investigating the antitumor potential in transplantable tumor models. Ascites tumor model is a type of rapidly growing carcinoma, which is inoculated in the outbred mice by serial intraperitoneal transplantation. Ascites fluid was aspirated from the tumor-bearing mice and injected to the normal mice. On $15^{\text {th }}$ day there was substantial increase in body weight of tumor control group animals. The maximum increment in the body weight was $75.0 \mathrm{~g}$ in mice bearing tumor. Treatment by ALCM and AQCM at the dose of $200 \mathrm{mg} / \mathrm{kg}$ substantially decreased the bodyweight to $37.1 \mathrm{~g}$ and $40.6 \mathrm{~g}$. It is quite evident that ALCM demonstrated more significant activity when compared to AQCM. MST enhanced by ALCM treatment at a dose of $200 \mathrm{mg} / \mathrm{kg}$. The life span was increased up to $31.87 \%$ by ALCM at a dose of $200 \mathrm{mg} / \mathrm{kg}$. AQCM $200 \mathrm{mg} / \mathrm{kg}$ also enhanced the survival time up to $27.47 \%$. \%ILS by $25 \%$ or more when compared to control is considered as an effective anticancer response. Both the extracts showed the enhancement in the life span, more than that of control. The influence of tumor growth on hematological and biochemical parameters is well established; hence, to assess the influence of ALCM and AQCM on the hematological parameters, the total RBC count, WBC count, and hemoglobin content of all the treated groups were checked on $15^{\text {th }}$ day of tumor inoculation. In tumor control animals, there was a significant rise in the WBC count. Treatment with ALCM and AQCM at $200 \mathrm{mg} / \mathrm{kg}$ dose reversed the enhanced WBC count in the treated group, which was more significant to that of control. Standard cyclophosphamide at $10 \mathrm{mg} / \mathrm{kg}$ dose decreased the cell count than the normal reflecting myelosuppression. There was a decrease in RBC count in the control group, which was restored by the treatment of ALCM and AQCM at $200 \mathrm{mg} / \mathrm{kg}$ dose. Ascites tumor-bearing mice reduced the hemoglobin content, which is a hallmark in iron deficiency. The therapy with ALCM and AQCM at $200 \mathrm{mg} / \mathrm{kg}$ reversed the tumor-induced alternation in hematological parameters.

\section{CONCLUSION}

The present study indicated that ALCM extract exhibited more antioxidant potential by well-established methods. Both the extracts of CM were assessed for their in vivo antitumor activity in both EAC and DLA transplantable tumor-bearing animals. Both the extracts reflected their cytotoxic potential as evident in vitro cytotoxicity assays such as brine shrimp lethality assay and Trypan blue cytotoxicity assay. ALCM exhibited more potent cytotoxicity as compared to AQCM. In the EAC model, ALCM showed a reduction in increased body weight, as well as an increment in the survival time, which indicates inhibition in the tumor progression. The alcoholic extract at the dose of $200 \mathrm{mg} / \mathrm{kg}$ body weight reversed the hematological parameters and restored the endogenous antioxidant and serum enzymes, which signed with that of control. In DLA model, ALCM at the doses $100 \mathrm{mg} / \mathrm{kg}$ and $200 \mathrm{mg} / \mathrm{kg}$ decreased the growth of the solid tumor as evidenced by the reduction of solid tumor weight and volume when compared with control. Both the extracts evaluated for their immunomodulatory activity in vivo. ALCM and AQCM screened for immunomodulatory models such as carbon clearance test and delayed-type hypersensitivity. ALCM exhibited low phagocytic index compared to the standard, which indicates its ability to enhance the carbon clearance rate. SRBC-induced delayed-type hypersensitivity was used to assess the effect of the extract on cell-mediated immunity. ALCM exhibited much reduction in the paw edema as compared to control. Therefore, the increase in DTH reaction to cell-dependent antigen showed the inhibitory effect of ALCM. 


\section{ACKNOWLEDGMENT}

The authors are thankful to Principal, JSS College of Pharmacy, Mysore, Academy of Higher Education and Research, Mysore, for providing the necessary infrastructure in completing the project.

\section{AUTHOR'S CONTRIBUTIONS}

Ms. Ankitha Deep performed the in vivo and in vitro studies at JSS College of Pharmacy, Ms. Sindhu R prepared the manuscript, Santhepete $\mathrm{N}$ Manjula and Kenaganora Mruthunjaya designed and guided to carry out the experiments and evaluated the result part of in vitro and in vivo studies and reviewed the manuscript.

\section{CONFLICTS OF INTEREST}

The authors declare that they have no conflicts of interest.

\section{REFERENCES}

1. Chanda D, Bhushan S, Guru SK, Shanker K, Wani ZA, Rah BA, et al. Anticancer activity, toxicity and pharmacokinetic profile of an indanone derivative. Eur J Pharm Sci 2012;47:988-95.

2. Mayakrishnan V, Kannappan P, Shanmugasundaram K, Abdullah N. Anticancer activity of Cyathula prostrata (Linn) blume against dalton's lymphomae in mice model. Pak J Pharm Sci 2014;27:1911-7.

3. Dahiru D, Obidoa O. Evaluation of the antioxidant effects of Ziziphus mauritiana Lam. Leaf extracts against chronic ethanol-induced hepatotoxicity in rat liver. Afr $\mathrm{J}$ Tradit Complement Altern Med 2007:5:39-45.

4. Meera R, Chidambaranathan N. Anti cancer activity of ethanolic extract of crataeva magna lour (DC) against ehrlich ascitic carcinoma cell lines in mice. J Pharm Sci 2017;9:5.

5. Nasrin M, Dash PR, Ali MS. In vitro antibacterial and in vivo cytotoxic activities of Grewia paniculata. Avicenna J Phytomed 2015;5:98-104.

6. Kumari TD, Madhuri T, Charya MA, Rao KS. Antioxidant and anticancer activities of nyctanthes arbor-tristis. Int J Pharm Pharm Sci 2012;4:452-4

7. Sreejayan N, Rao MN. Free radical scavenging activity of curcuminoids. Arzneimittelforschung 1996;46:169-71.

8. Oszmiański J, Wojdyło A. Comparative study of phenolic content and antioxidant activity of strawberry puree, clear, and cloudy juices. Eur Food Res Technol 2009;228:623-31.

9. Ghosal M, Mandal PK. Phytochemical screening and antioxidant activities of two selected "bihi" fruits used as vegetables in Darjeeling
Himalaya. Int J Pharm Pharm Sci 2012;4:567-74

10. Ghosh S, Derle A, Ahire M, More P, Jagtap S, Phadatare SD, et al. Phytochemical analysis and free radical scavenging activity of medicinal plants gnidia glauca and Dioscorea bulbifera. PLoS One 2013;8:e82529.

11. Weisenthal LM, Marsden JA, Dill PL, Macaluso CK. A novel dye exclusion method for testing in vitro chemosensitivity of human tumors. Cancer Res 1983;43:749-57.

12. Meyer BN, Ferrigni NR, Putnam JE, Jacobsen LB, Nichols DE, McLaughlin JL, et al. Brine shrimp: A convenient general bioassay for active plant constituents. Planta Med 1982;45:31-4.

13. Manjula SN, Kenganora M, Parihar VK, Kumar S, Nayak PG, Kumar N, et al. Antitumor and antioxidant activity of polyalthia longifolia stem bark ethanol extract. Pharm Biol 2010;48:690-6.

14. Kumar N, Dhamija I, Raj PV, Jayashree BS, Parihar V, Manjula SN, et al. Preliminary investigation of cytotoxic potential of 2-quinolone derivatives using in vitro and in vivo (solid tumor and liquid tumor) models of cancer. Arab J Chem 2014;7:409-17.

15. Eckhardt AE, Malone BN, Goldstein IJ. Inhibition of Ehrlich ascites tumor cell growth by Griffonia simplicifolia I lectin in vivo. Cancer Res 1982;42:2977-9.

16. Mukherjee A, Hazra S, Dutta S, Muthiah S, Mondhe DM, Sharma PR, et al. Antitumor efficacy and apoptotic activity of substituted chloroalkyl 1H-benz[de]isoquinoline-1,3-diones: A new class of potential antineoplastic agents. Invest New Drugs 2011;29:434-42.

17. Kumar RS, Rajkapoor B, Perumal P. Antitumor and cytotoxic activities of methanol extract of Indigofera linnaei Ali. Asian Pac J Cancer Prev 2011;12:613-8.

18. Thefeld W, Hoffmeister H, Busch EW, Koller PU, Vollmar J. Reference values for the determination of GOT, GPT, and alkaline phosphatase in serum with optimal standard methods (author's transl). Dtsch Med Wochenschr 1974;99:343-4 passim

19. Kori ML, Gaur K, Dixit VK. Investigation of immunomodulatory potential of Cleome gynandra Linn. Asian J Pharm Clin Res 2009;2:5.

20. ANE, Mathew L. In vitro cytotoxicity and antimicrobial efficacy of Thevetia peruviana seed kernel extracts. Int J Pharm Pharm Sci 2016;8:47-50.

21. Tripathi S, Maurya A, Kahrana M, Kaul A, Sahu R. Immunomodulatory property of ethanolic extract of Trigonella foenum-graeceum leaves on mice. Pharm Lett 2012;4:2708-13.

22. Lamont AG, Bruce MG, Watret KC, Ferguson A. Suppression of an established DTH response to ovalbumin in mice by feeding antigen after immunization. Immunol 1988;64:135-9.

23. Oyaizu M. Studies on products of browning reaction. Antioxidative activities of products of browning reaction prepared from glucosamine. Jpn J Nutr Diet 1986;44:307-15. 